\title{
Exploring the Use of Faded Worked Examples as a Problem Solving Approach for Underprepared Students
}

\author{
Tiffany L. Hesser ${ }^{1} \&$ Jess L. Gregory ${ }^{2}$ \\ ${ }^{1}$ Department of Chemistry and Chemical Engineering, University of New Haven, West Haven, CT, United \\ States \\ ${ }^{2}$ Department of Educational Leadership and Policy Studies, Southern Connecticut State University, New Haven, \\ CT, United States \\ Correspondence: Tiffany L. Hesser, Department of Chemistry and Chemical Engineering, University of New \\ Haven, 300 Boston Post, West Haven, CT, United States. Tel: 1-203-931-2982. Email: thesser@newhaven.edu
}

Received: October 2, 2015

Accepted: November 3, 2015

Online Published: November 15, 2015

doi:10.5539/hes.v5n6p36

URL: http://dx.doi.org/10.5539/hes.v5n6p36

\begin{abstract}
It is not uncommon for students to find themselves underprepared when entering a post secondary institution. In additional to lower levels of academic achievement, underprepared students may not be aware that they lack the skills needed to be successful and effectively acquire and process information. Because of this, students that enter post-secondary institutions underprepared often require more support in and out of the college classroom.

In computational based classes, such as math, engineering, chemistry or physics, this support often includes an introduction to effective problem solving strategies. This study introduced faded worked examples as a problem solving approach to students identified as mathematically underprepared in a college chemistry course. Faded worked examples are similar to worked examples but fade out steps for students to complete, allowing support within the problem solving approach as learning improves. The goal of this study was to explore students' perceptions of this problem solving approach and their belief in its potential to enhance their learning, particularly with students identified as academically underprepared. Overall, students reported that faded worked examples enhanced their overall learning and problem solving abilities in chemistry and the step by step process allowed for a better understanding of the course material.
\end{abstract}

Keywords: faded worked examples, learning strategies, problem solving, remedial education, underprepared in higher education, worked examples

\section{Introduction}

Colleges and universities seek to create an environment where all students that enroll persist to graduation; this has evolved to include embedding support for students that are underprepared for college level work. Remediation of students that enter college without the skills to be successful costs colleges and universities more than just dollars. Bailey (2009) reported not only on the financial costs for institutions and students, but also the psychological costs for the students and policy ramifications as faculty look for ways to "help" students through.

Forced into the role of gatekeepers, institutions seek to balance the competing demands of enrollment targets, high standards, and providing support systems intended to retain students through graduation. There is confusion as to what best practices are for remediation and the level of benefit students gain and even less consensus on evidence-based strategies for embedded support in computation based courses at the post-secondary level (Bailey, 2009). At a personal level, a lack of preparedness can affect an individual's success in the classroom and even impact student's levels of self-esteem (Venzia, Kirst, \& Antonio, 2004). At a larger level, universities that do not adequately address college-readiness experience a decrease in retention rates for students (Chan, 2013).

\subsection{Underprepared and Unaware}

Students entering college today are likely to believe that they are above average in academic ability and are increasingly optimistic about how they will preform (Twenge, 2009). Countering their opinions are reports on standardized assessment outcomes that have shown students entering college today are not testing at college-ready levels. Only $22 \%$ to $25 \%$ of students met the test's readiness benchmarks in reading, math and science from 2008 through 2012 on the ACT, a standardized assessment that is aimed to measure high school 
achievement and commonly used for college admissions in the United States. (ACT, Inc., 2011; ACT, Inc., 2012; Bautsch, 2011).

Despite their optimism, these underprepared students may not be aware that they were lacking the skills they need to be successful (Galindo, Castaneda, Gutierrez, Tejada Jr., \& Wallace, 2014). They do not know how to effectively acquire and process information and often lack the ability to objectively rate their own cognitive proficiencies (Boylan \& Saxon, 2005; Kruger \& Dunning, 1999). Swimming against a tide of grade inflation and social promotions colleges and universities seek to hold high standards, while maintaining high graduation rates. Therefore, students that enter post-secondary institutions may require more support to be academically successful than in the past, and these institutions are motivated from a variety of angles to provide these supports.

There are many general learning strategies recommended for students identified as underprepared, such as concept mapping, reading approaches, the study cycle, distributed practice, peer instruction and group problem solving (Boylan \& Saxon, 2005; Hoffman \& McGuire, 2010; Rickey \& Stacy, 2000) While generic strategies are helpful for all students in many classes, calculation-based courses require more targeted types of supports. Worked examples are recommended as an instructional strategies in computational courses as they can provide support while a novice learner becomes more skilled in problem solving (Crippen, 2009) and have been found to contribute to the mastery of problem solving (Taconis, Ferguson-Hessler, \& Broekkamp, 2001).

\subsection{Worked Examples}

A worked example is a step-by-step demonstration of how to perform a problem (Figure 1). The goal is to introduce students to a proper pathway determination, procedure process and final answer. Instructional explanations are usually provided within the problem, but do not always articulate the solution steps and only provide the problem formulation and final solution (Crippen \& Brooks, 2009).

\section{Question:}

How many $\mathrm{mL}$ of $0.383 \mathrm{M} \mathrm{HCl}$ are needed to react with $16.2 \mathrm{~g}$ of $\mathrm{CaCO}_{3}$ in the reaction:

$$
2 \mathrm{HCl}(a q)+\mathrm{CaCO}_{3}(s) \rightarrow \mathrm{CaCl}_{2}(a q)+\mathrm{CO}_{2}(g)+\mathrm{H}_{2} \mathrm{O}(l)
$$

Plan:

Convert the mass of calcium carbonate to moles and use the balanced equation to find the moles of hydrochloric acid required. The moles of acid, along with the molarity of the acid will give the volume required. The molarity of the solution is given as moles per liter.

Solution:

Volume required $=16.2 \mathrm{~g} \mathrm{CaCO}_{3}\left(\frac{1 \mathrm{~mol} \mathrm{CaCO}_{3}}{100.09 \mathrm{grams} \mathrm{CaCO}_{3}}\right)\left(\frac{2 \mathrm{~mol} \mathrm{HCl}}{1 \mathrm{~mole} \mathrm{CaCO}_{3}}\right)\left(\frac{1 \mathrm{~L} \mathrm{HCl}}{0.383 \mathrm{~mol} \mathrm{HCl}}\right)\left(\frac{1000 \mathrm{~mL}}{1 \mathrm{~L}}\right)=845 \mathrm{ml} \mathrm{of} \mathrm{HCl}$

Figure 1. A general representation of a worked example in general chemistry

The use of worked examples and its success has been explained using the cognitive load theory. According to the theory, schema construction and automation are the primary functions of learning and the learning process may be inhibited if a learner is required to devote limited working memory resources to activities that are not directly related to schema construction and automation (Kalyuga, Chandler, Tuovinen, \& Sweller, 2001). Working memory, in which all conscious cognitive processing occurs, can handle only a very limited number-possibly no more than two or three-novel interacting elements (Paas, Renkly, \& Sweller, 2003). Conventional open-ended calculation problems impose a heavy working memory load. Worked examples provide learners with instructional steps including explanations, which reduce the cognitive load because it obviates the need for means-ends search. Practice within worked examples can then assist in the long-term memory process, which provides the ability to vastly expand this processing ability for later use. This memory store can contain vast numbers of schemas - cognitive constructs that incorporate multiple elements of information into single element with a specific function (Paas et al., 2003).

Worked examples are commonly employed until students are assumed to have obtained a basic familiarity with new material. The procedure is then frequently abandoned beyond this point to be replaced by conventional open-ended calculation based problems (Sweller \& Cooper, 1985), which may be insufficient to meet the needs of underprepared students. To assist in the transition, the use of faded worked examples has been introduced, where worked steps are faded out and instead completed by the student with an explanation of procedural importance of the step (Figure 2). The concept behind faded worked examples is learning from scaffolding, 
where support is provided to learners but removed, or faded, as the learners' skill improve (Atkinson, Renkl, \& Merrill, 2003).

\begin{tabular}{|l|l|}
\hline \multicolumn{2}{|l|}{$\begin{array}{l}\text { Question 1:How many } \mathrm{mL} \text { of } 0.383 \mathrm{M} \mathrm{HCl} \text { are needed to react with } 16.2 \mathrm{~g} \text { of CaCO} \\
\text { 2 in the reaction: }\end{array}$} \\
\hline $\begin{array}{l}\text { Step 1: Convert the mass of the given to moles } \\
\text { using the molar mass }\end{array}$ & $16.2 \mathrm{~g} \mathrm{CaCO}_{3}\left(\frac{1 \mathrm{~mol} \mathrm{CaCO}_{3}}{100.09 \mathrm{grams} \mathrm{CaCO}_{3}}\right)=.16185 \mathrm{~mol} \mathrm{CaCO}_{3}$ \\
\hline $\begin{array}{l}\text { Step 2: Used the balance equation to determine } \\
\text { the molar ratio of the chemicals being examined }\end{array}$ & $.16185 \mathrm{~mol} \mathrm{CaCO}_{3}\left(\frac{2 \mathrm{~mol} \mathrm{HCl}_{3}}{1 \mathrm{~mole} \mathrm{CaCo}}\right)=.32371 \mathrm{~mol} \mathrm{HCl}$ \\
\hline $\begin{array}{l}\text { Step 3: Use the molarity given to convert the } \\
\text { moles to volume requested }\end{array}$ & $.32371 \mathrm{CaCl} \mathrm{HCl}_{2}\left(\frac{1 \mathrm{~L} \mathrm{HCl}}{0.383 \mathrm{~mol} \mathrm{HCl}}\right)\left(\frac{1000 \mathrm{~mL}}{1 \mathrm{~L}}\right)=835.19 \mathrm{~mL} \mathrm{HCl}$ \\
\hline $\begin{array}{l}\text { Step 4: Consider significant figures and rounding } \\
\text { for final answer and restate the answer }\end{array}$ & $\begin{array}{l}845.19 \mathrm{~mL} \mathrm{HCl} \rightarrow 845 \mathrm{~mL} \mathrm{HCl} \mathrm{required} \mathrm{to} \mathrm{react} \mathrm{with} \\
16.2 \mathrm{~g} \mathrm{CaCO}_{3}\end{array}$ \\
\hline
\end{tabular}

\begin{tabular}{|c|c|}
\hline \multicolumn{2}{|c|}{$\begin{array}{l}\text { Question 2: How many } \mathrm{mL} \text { of } 0.500 \mathrm{M} \mathrm{HCl} \text { are needed to react with } 18.6 \mathrm{~g} \text { of } \mathrm{Mg}(\mathrm{OH})_{2} \text { in the reaction: } \\
\qquad 2 \mathrm{HCl}(a q)+\mathrm{Mg}(\mathrm{OH})_{2}(s) \rightarrow \mathrm{MgCl}_{2}(a q)+2 \mathrm{H}_{2} \mathrm{O}(I)\end{array}$} \\
\hline $\begin{array}{l}\text { Step 1: Convert the mass of the given to moles } \\
\text { using the molar mass }\end{array}$ & $18.6 \mathrm{gg}(\mathrm{OH})_{2}\left(\frac{1 \mathrm{~mol} \mathrm{Mg}(\mathrm{OH})_{2}}{58.32 \mathrm{grams} \mathrm{Mg}(\mathrm{OH})_{2}}\right)=.31893 \mathrm{~mol} \mathrm{Mg}(\mathrm{OH})_{2}$ \\
\hline $\begin{array}{l}\text { Step 2: Used the balance equation to determine } \\
\text { the molar ratio of the chemicals being } \\
\text { examined }\end{array}$ & $.31893 \mathrm{~mol} \mathrm{Mg}(\mathrm{OH})_{2}\left(\frac{2 \mathrm{~mol} \mathrm{HCl}}{1 \mathrm{~mole} \mathrm{Mg}(\mathrm{OH})_{2}}\right)=.63786 \mathrm{~mol} \mathrm{HCl}$ \\
\hline $\begin{array}{l}\text { Step 3: Use the molarity given to convert the } \\
\text { moles to volume requested }\end{array}$ & $.63786 \mathrm{~mol} \mathrm{HCl}\left(\frac{1 \mathrm{~L} \mathrm{HCl}}{0.500 \mathrm{~mol} \mathrm{HCl}}\right)\left(\frac{1000 \mathrm{~mL}}{1 \mathrm{~L}}\right)=1275.72 \mathrm{~mL} \mathrm{HCl}$ \\
\hline & \\
\hline
\end{tabular}

\begin{tabular}{|l|l|}
\begin{tabular}{|l|} 
Question 3:How many mL of $0.257 \mathrm{M} \mathrm{HCl}$ are needed to react with $11.5 \mathrm{~g}$ of $\mathrm{MgCO}_{3}$ in the reaction: \\
$2 \mathrm{HCl}(\mathrm{aq})+\mathrm{MgCO}_{3}(\mathrm{~s}) \rightarrow \mathrm{MgCl}_{2}(\mathrm{aq})+\mathrm{CO}_{2}(\mathrm{~g})+\mathrm{H}_{2} \mathrm{O}(\mathrm{I})$
\end{tabular} \\
\hline $\begin{array}{l}\text { Step 1: Convert the mass of the given to moles } \\
\text { using the molar mass }\end{array}$ & $11.5 \mathrm{ggCO}\left(\frac{1 \mathrm{~mol} \mathrm{MgCO}_{3}}{84.31 \mathrm{grams} \mathrm{MgCO}_{3}}\right)=.13640 \mathrm{~mol} \mathrm{MgCO}_{3}$ \\
\hline $\begin{array}{l}\text { Step 2: Used the balance equation to determine } \\
\text { the molar ratio of the chemicals being examined }\end{array}$ & $.13640 \mathrm{~mol} \mathrm{MgCO}_{3}\left(\frac{2 \mathrm{~mol} \mathrm{HCl}_{1}}{1 \mathrm{~mol} \mathrm{MgCO}_{3}}\right)=.27280 \mathrm{~mol} \mathrm{HCl}$ \\
\hline Step 3: & \\
\hline Step 4: & \\
\hline
\end{tabular}

\begin{tabular}{|c|c|}
\hline \multicolumn{2}{|c|}{$\begin{array}{l}\text { Question 4:How many } \mathrm{mL} \text { of } 0.650 \mathrm{M} \mathrm{HCl} \text { are needed to react with } 20.5 \mathrm{~g} \text { of } \mathrm{CaCO}_{3} \text { in the reaction: } \\
\qquad 2 \mathrm{HCl}(a q)+\mathrm{CaCO}_{3}(s) \rightarrow \mathrm{CaCl}_{2}(a q)+\mathrm{CO}_{2}(g)+\mathrm{H}_{2} \mathrm{O}(I)\end{array}$} \\
\hline $\begin{array}{l}\text { Step 1: Convert the mass of the given to moles } \\
\text { using the mular mass }\end{array}$ & $20.5 \mathrm{~g} \mathrm{CaCO}_{3}\left(\frac{1 \mathrm{~mol} \mathrm{CaCO}_{3}}{100.09 \mathrm{grams} \mathrm{CaCO}_{3}}\right)=.20317 \mathrm{~mol} \mathrm{CaCO}_{3}$ \\
\hline \multicolumn{2}{|l|}{ Step 2: } \\
\hline \multicolumn{2}{|l|}{ Step 3: } \\
\hline Step 4: & \\
\hline
\end{tabular}

\begin{tabular}{|l|l|}
\hline \multicolumn{2}{|c|}{ Question 5:How many mL of 0.475M HCl are needed to react with 12.6g of $\mathrm{Mg}(\mathrm{OH})_{2}$ in the reaction: } \\
$\qquad 2 \mathrm{HCl}(a q)+\mathrm{Mg}(\mathrm{OH})_{2}(s) \rightarrow \mathrm{MgCl}_{2}(a q)+2 \mathrm{H}_{2} \mathrm{O}(I)$ \\
\hline Step 1: & \\
\hline Step 2: & \\
\hline Step 3: & \\
\hline Step 4: & \\
\hline
\end{tabular}

Figure 2. A general representation of a series of faded worked examples where blank steps are completed 
In backward fading, learners first studied a worked out example. In the next problem, the early steps were worked out and the learner had to attempt the final step. In the following problem, only the initial solution step was worked out and the learners had to attempt solving the remaining solution steps. Forward fading was analogous but required the learners to attempt the first solution step in problem 1, the first two steps in problem 2 , and all three steps in problem 3.

Worked examples have been shown to give better outcomes than open-ended inquiry projects without scaffolding (Taconis et al., 2001). Fading worked examples leads to higher transfer performance and enhanced student learning (Moreno, Reisslein, \& Delgoda, 2006; Salden, Aleven, Renkl, \& Schwonke, 2009). These faded worked examples provide structure within the problems that allow students to move through the exercise with confidence. The students' comfort and confidence in solving calculation-based problems supports their self-efficacy and improves their skills to lessen the gap between their perceived competence and their actual competence. Thus reducing the cognitive dissonance that they may experience when their overly optimist perception of themselves is challenged.

\subsection{Focus of Inquiry}

This study introduced faded worked examples to students identified as underprepared in a college chemistry course. This was done as a variation to worked examples to allow support within the problem solving approach as learning improves. Since it's introduction, limited research studies have examined the success of faded worked example but determined this approach to be an effective problem solving strategy in science, engineering and mathematics education (Crippen, Biesinger, Muis, \& Orgill, 2009; Flores \& Inan, 2014; Moreno, Reisslein, \& Delgoda, 2006). The goal of this study was to explore students' perceptions of this problem solving approach and its potential to enhance their learning, particularly with students identified as academically underprepared.

\section{Method}

\subsection{Identification of Underprepared Participants}

This inquiry focused on students identified as just below grade level in math by the institution. Academic readiness for the college level chemistry course was determined using math placement scores. Math placement exams were created within the institution by the Department of Mathematics and had not been analyzed for validity or reliability.

Students who score higher than $70 \%$ on the math placement exam are placed into Pre-calculus or Calculus, depending on the score. These students are identified as college ready. Student scoring lower than $70 \%$ on the math placement exam are considered academically underprepared in math within the scope of this study. To validate math placement exam scores, the math SAT scores of participants were compared to students identified as college-ready that had been placed directly into a college level chemistry course. This comparison was done using an independent sample t-test.

Math placement scores are used for separation of prepared versus underprepared students at this university because many topics addressed in a first year chemistry course require application of algebraic functions and are analytical in nature. Therefore, chemistry readiness is defined in terms of math achievement levels as students identified as underprepared in mathematics may not be able to complete the calculation-based components in a college chemistry course.

\subsection{Faded Worked Example Intervention for Underprepared Participants}

Students identified as underprepared were required to attend additional instructional sessions throughout the semester. These instructional sessions were embedded into the course and added 75 minutes to the weekly course time. Instructional sessions were organized to reinforce lecture content and provide extra practice time for students. The small study groups and added study time has been recommended for students requiring remediation in higher education (Boylan \& Saxon, 2005; Martin \& Arendale, 1994; National Conference of State Legislatures, 2012).

Each session was lead by a Teaching Assistant (TA) working in small groups with a maximum of 12 students. The sessions focused on faded worked examples as a primary problem solving strategy. In order to provide effective support, Boylan and Saxon (2005) recommended formal training for tutors working with students identified as underprepared. Therefore, TAs participated in an initial 15-hour training period prior to the start of the semester provided by the Director of the Center for Learning Resource. Thirteen hours covered materials available from the College Reading and Learning Association, which provides certified tutor-training programs in postsecondary educational institutions. TAs were also trained for two additional hours in metacognitive awareness, the role of motivation in learning and calculation-based problem solving strategies for chemistry 
students, which included worked and faded worked examples.

\subsection{Feedback Surveys}

Faded Worked Example Feedback Surveys were distributed on the last day of class and collected by TA. The surveys presented students with 14 statements regarding the course material and faded worked examples. The statements were designed to be answered using a one through 10 scale, indicating the extent to which they agreed (10) or disagreed with each of the statements (1). To determine if there were redundancies among the survey statements, the survey items were analyzed using a factor analysis. Suitability of the data for factor analysis was assessed using a Kaiser-Meyer-Olkin output, which resulted in a value of .743, a middling value, demonstrating that the analyses are appropriate. Based on the results of the principal component analysis, three factors were retained; material complexity, enhancement of understanding, and difficulty of problems. The reliability for each was factor was calculated using Cronbach's alpha, which demonstrated very good reliability values of $.813, .962$ and .833 , respectively.

The three factors that were retained for examination within the study (material complexity, enhancement of understanding, and difficulty of problems) were examined using mean and standard deviation of responses from the survey results. Responses to questions within each component were averaged to obtain a single mean score and standard deviation. To determine whether students felt they needed support, two factors on the survey were used; material complexity and difficulty of problems. The data from the third factor, enhancement of understanding, helped to evaluate student preferences.

The Faded Worked Examples Feedback Surveys also provided an opportunity for students to give open-ended feedback. Additional questions regarding the advantages and disadvantages to the faded worked examples as well as questions regarding student preferences in problem solving methods used as compared to other methods and experiences. The results from these surveys were coded for common phrasing within the open-ended questions.

\subsection{Student Performance}

To evaluate student performance in General Chemistry 1, exam scores were compared using 14 common questions. These questions were multiple-choice and calculation based with four possible responses for each questions. Common questions relevant to the material covered in General Chemistry lecture were placed on each exam (Exam 1, 2 and 3). These questions were identical for all students in this study, those identified as underprepared and college ready. Question responses were recorded for all students on a dichotomous scale.

The final exam was also used as a measurement of student performance and consisted of a standardized final provided by the Department of Chemistry. The exam consisted of 45 questions; 25 multiple-choice questions and 20 open-ended questions. Open-ended questions were allowed partial credit grading by instructors for course grades, but for assessment purposes, results were recorded for every student on a dichotomous scale.

\section{Results}

\subsection{Participation Levels}

Forty-seven students identified as underprepared in math that were enrolled in a general chemistry course at a private 4-year institution participated in a survey given on the last day of the intervention class that featured faded worked examples. The course began in August of 2014, and was completed in December of 2014 Ninety-two student were enrolled in the intervention course when it began. The surveys were given to student on the $14^{\text {th }}$ week of classes and 47 students participated. The remaining students had either withdrawn (21) from the course, chose not to return the survey or were not present in class that day (24).

\subsection{Confirmation of Underprepared Participants}

To confirm the student group being examined was underprepared in math, math placement exam scores and math SAT scores of this group were compared to students identified as college-ready that had been placed directly into a college level chemistry course. Scores indicated that the two student groups had significant differences in the means for both assessments. Math placement scores for underprepared students $(M=52.88, S D=13.73, N=58)$ and college-ready $(M=87.14, S D=13.73, N=212)$ were determined to be significantly different using a independent sample $t$-test, $t(268)=-14.66, p<.001$. SAT math scores were also analyzed for underprepared students $(M=538.7$, $S D=57.61, N=51)$ and college-ready $(M=568.0, S D=70.07, N=205)$ were determined to be significantly different using a independent sample $t$-test, $t(254)=-2.76, p<.05$. Overall, the analysis of entrance exams scores indicated that students labeled as underprepared had entrance assessment averages significantly lower than college-ready students when entering the General Chemistry course. These results indicated a lower level of math proficiency 
and supported the identification of these students as underprepared for the chemistry course.

\subsection{Survey Results}

Two of the three factors from the survey focused on how challenging the student believe the course content to be. The harder the material was considered, the more that students identified as underprepared would need additional support in problem solving strategies. Student perception of material complexity in chemistry was measured using three questions asking if the topics, formula, concept and definitions were complex. The responses indicated that the students did find the material covered in the chemistry course complex. Students were also asked if the faded worked examples presented over the semester required large amounts of mental effort or were difficult. The responses indicated that the students did find problems challenging (Table 1).

Table 1. Faded worked example survey component results

\begin{tabular}{llll}
\hline & $\mathrm{N}$ & Mean & Std. Dev \\
\hline Material Complexity & 47 & 6.49 & 1.74 \\
Enhancement of Understanding & 47 & 7.56 & 1.82 \\
Difficulty of Problems & 47 & 6.51 & 1.75 \\
\hline
\end{tabular}

Students were also asked whether the experience using faded worked examples enhanced their knowledge of the topics, formulas, concept and definitions. The responses indicated that the students did believe that the use of faded worked examples enhanced their knowledge. The surveys regarding faded worked examples also included four questions allowing the students to provide additional comments. These questions asked for feedback regarding the use of faded worked examples throughout the semester. To address the research questions specifically regarding students' preference, students were asked if they would prefer faded worked examples in comparison to the typical questions presented for problem solving. These open-ended responses were coded for affirmative responses, with 35 of the 47 responses replying with yes and the remaining students requesting a combination of both types of problems. Typical student responses included, the "faded problems allow you to understand them. Then test what you learned" and "it helped me learn the material better because it helped me learn and understand the steps to solving a problem rather than just memorizing".

Finally, students were asked about their perception of learning regarding the material when faded worked examples were provided. Open-ended responses were again coded for affirmative response, with 37 of the 47 responses specifically indicating that these problems enhanced their learning. Students were also asked to provide feedback on any advantages to the faded worked examples. These responses were also grouped with 9 students reporting a better understanding of the material ("You are integrated into the problem solving process, allowing you to better understand the process"), 3 students reporting a more organized approach to their own learning ("Faded worked examples helped me get a better picture of how to solve the problems. It also helped me get more organized") and 15 students responding in appreciation of the step-by-step approach that faded worked examples provided ("They allowed a way to see the process for solving the problem and ease into it").

Table 2. Student responses to open ended survey questions

- You are integrated into the problem solving process, allowing you to better understand the process

- Faded worked examples helped me get a better picture of how to solve the problems. It also helped me get more organized

- They allowed a way to see the process for solving the problem and ease into it

- They helped me focus on what the next step was and how I should approach problems when I do them myself

- They showed me how the problem was supposed to be carried out and then lets me work through

- The process helps to learn by repetition while slowly solving more and more of the problems on our own

Note. Responses are limited to those included within the Results and Discussion 


\subsection{Student Performance}

Common question results were also analyzed for underprepared and college-ready students within the study. The analysis was done to compare student performace over the course of the semester for those identified as college ready versus underprepared. The results were analyzed using the percent correct response (Figure 3). The results indicate that as the semester progressed, underprepared student began to outperform their college ready peers on common questions.

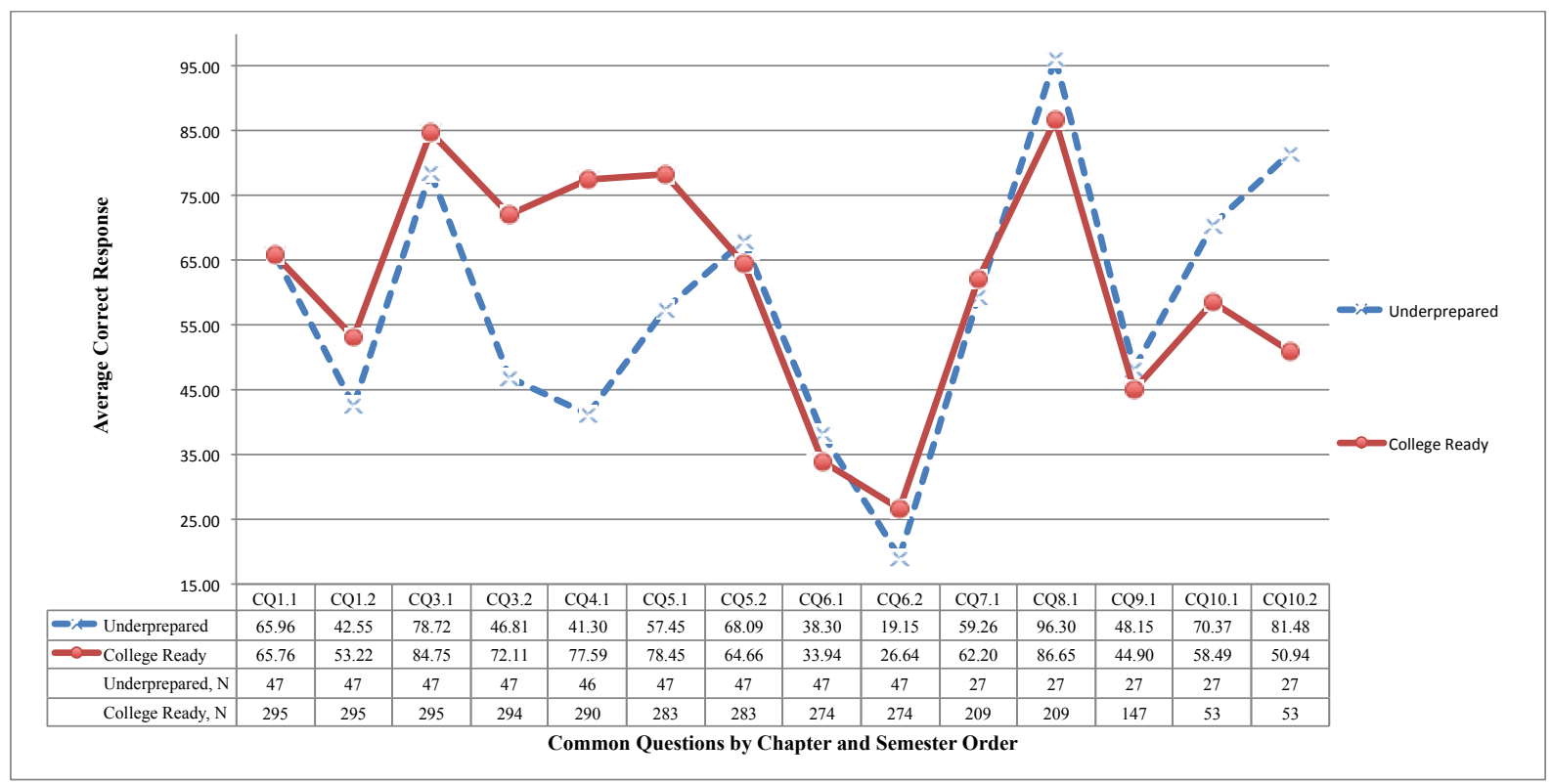

Figure 3. Percentage of correct response in common question responses graphed for students identified as underprepared and for college-ready by chapter

In addition to the common questions, student performance was also examined using final exam scores. Final exam responses were also analyzed in more detail for students identified as underprepared and college-ready with the study (Figure 4). When comparing mean correct responses of multiple choice questions for students identified as underprepared and college-ready, the results indicated the students identified as underprepared $(M=15.46, S D=3.28, N=45)$ were slight higher compared college-ready students $(M=15.08, S D=4.53, N=250)$. When comparing mean correct responses of open-ended questions for students identified as underprepared and college-ready, the results indicated the students identified as underprepared $(M=15.76, S D=5.19, N=45)$ were also higher than college-ready students $(M=13.94, S D=6.32, N=250)$.

The higher performance on open-ended responses by the students identified as underprepared is of particular interest as open-ended questions require different cognitive processes and have a different level of cognitive load than do the multiple choice questions (Birenbaum \& Tatsuoka, 1987). Students tend to use cues from distractors to reduce the cognitive load when responding to multiple-choice questions (Birenbaum \& Tatsuoka, 1987) and tend to require less higher-order thinking and more recall of factual knowledge (Palmer \& Devitt, 2007). The results of this study indicate that the students that were identified as underprepared surpassed their college ready peers on the multiple choice and significantly outperformed the college-ready students on the open-ended questions. The faded worked problem strategy was effective in supporting these students identified as underprepared to perform well in a college chemistry course. 


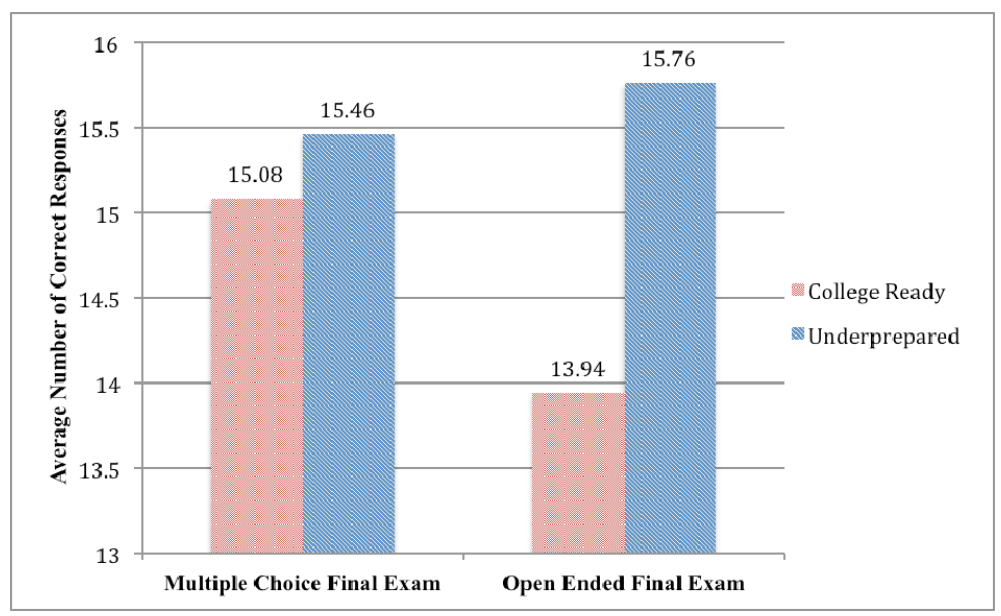

Figure 4. Average number of correct responses in mutiple choice questions and open ended questions on final exam

\section{Discussion}

This study sought to explore the perceptions of students identified as underprepared in regards to their preference in problem solving methods in a college chemistry course, specifically surrounding the use of faded worked examples. Faded worked examples assist in the transition from worked examples to conventional open-ended problems. In faded worked examples, problem steps are faded out and instead completed by the student with an explanation of procedural importance of the step. Fading worked examples leads to higher transfer performance and enhanced student learning (Moreno et al., 2006; Salden et al., 2009).

The results suggest that there is a need for purposeful use of effective problem solving strategies, such as faded worked examples, for students identified as underprepared in math. This need is indicated with students reporting that the material for the course was challenging. Students consider the material challenging, indicating a need for added support in problem solving strategies, particularly for a population of students that have been identified as underprepared in math. The means response values for the complexity and difficultly components were only slightly high if considering five a neutral point on the scale. Within these results should be the consideration that students are overly optimistic about how they perform (Twenge, 2009), even more so with students identified as unskilled that have been found to overestimate their ability considerably (Kruger \& Dunning, 1999). Therefore, the slight need reported is likely an underestimation of the actual level of need for these students to have effective problem solving strategies purposefully embedded in the course.

Even though students reported the difficulty associated with faded worked examples slightly high, most believed that the faded worked examples assisted in learning the material better than the use of typical open-ended problem solving approaches. Conventional open-ended calculation based problems are insufficient to meet the needs of underprepared students and while worked examples introduce students to a proper pathway determination and procedure process, they do not always articulate the solution steps (Crippen \& Brooks, 2009) leaving student confused as to the overall process. Faded worked examples provide a more structured problem solving approach compared to open-ended problem and students believed that the use of this particular learning strategy did enable them to better learn the material (79\%). The majority of students (74\%) preferred the faded worked examples to conventional open-ended type problems. Nearly a third of the students (32\%), included a specific reference to the step-by-step approach providing added support, guiding students through the problem when they were unsure how to proceed, they "helped me focus on what the next step was and how I should approach problems when I do them myself'.

Students also identified a better level of understanding associated with the use of faded worked examples (19\%). Responses from students regarding the problem solving strategies indicate that faded work examples "showed me how the problem was supposed to be carried out and then lets me work through". The process "helps to learn by repetition while slowly solving more and more of the problems on our own". These reponses were supported by two measure of student performance. Common questions were used to compare student performace over the course of the semester for those identified as college ready versus underprepared. While the population of students identified as underprepared clearly underperformed in comparison to their college ready peers on initial 
SAT scores, math placement scores and early common questions, as their exposure to the faded worked example intervention increased, so did their common question results. Students identified as underprepared scored significantly lower than college-ready peers early in the semester, but had comparitievly consistent scores at the midpoint. Towards the end of the semester, student identified as underprepared actually outperform their college ready peers (Figure 3). This successful performance coincides with approximately 10 to 13 weeks of exposure to the learning intervention that utilized faded worked examples as a problem solving strategy. Additionally, students indentified as underprepared outperformed college ready students on both sections of the common final exam.

The increasing trend in the common question results and the final exam scores supports students' beliefs that the faded worked example intervention assisted in providing a better understanding of the material. These finding are consistent with international based research on problem solving approaches included fading within examples as an effective learning strategy (Atkinson et al., 2003; Salden et al., 2009). This particular investigation into faded worked examples indicated that students identified as underprepared preferred the structured step-by-step approach of faded-worked examples and this problem solving strategy assisted in their success within the college chemistry course.

\subsection{Conclusion}

While there are additional problem-solving strategies that could have proven as influential on effective learning over the 14-week period, this investigation into faded worked examples indicated that students preferred the structured step-by-step approach of faded-worked examples to more open-ended approaches. Students, even those that are "college ready", find the material covered in a typical college chemistry course complex and difficult (Eddy, 2000; Kurbanoglu \& Akim, 2010) indicating a need for an effective problem-solving approach within the computational based course. This need for support in computational classes is even greater for those students that are underprepared.

The underprepared student, even if they recognize that they need support, is less likely to seek out the extra help they may need to build their skills. Students, particularly those that are underprepared, are not well suited to judge their own needs, but faculty and institutions of higher education do have the expertise to make those evaluations. In order to meet the identified needs of this at risk population, faculty and institutions can use the results of this research to embed instructional support sessions that use faded worked examples into courses. This will support all students, and is especially important to students that have been identified as underprepared.

Students that are identified as underprepared are admitted to colleges and universtites around the United States. Once admitted, these institutions have an obligation to meet the needs of these underprepared students, with increasing pressures to do so within the general program of studies and not through non-credit bearing developmental courses. While underprepared students may not know that they need added support and assistance with strategies such as faded worked examples, they do prefer it. With this information about student preferences, institutions can leverage that into higher student satisfaction and increased enrollments. It behooves universities to maximize student-preferred methods in calculation-based classes as these classes have the reputations of gatekeeper courses. The adoption of student preference centered approaches to teaching, such as faded worked examples, builds the reputation of an institution as responsive to student needs and therefore more attractive to prospective students and their parents. This reputation is further enhanced by higher percentages of students successfully completing their calculation-based classes and persisting to graduation.

\section{References}

ACT, Inc. (2011). The condition of college and career readiness 2011. Retrieved from http://www.act.org

ACT, Inc. (2012). The condition of college and career readiness 2012. Retrieved from http://www.act.org

Atkinson, R. K., Renkl, A., \& Merrill, M. (2003). Transitioning from studying examples to solving problems: Effects of self-explanation prompts and fading worked-out steps. Journal of Educational Psychology, 95(4), 774-783. http://dx.doi.org/10.1037/0022-0663.95.4.774

Bailey, T. (2009). Challenge and opportunity: Rethinking the role and function of developmental education in community college. New Directions for Community Colleges, 145, 11-30. http://dx.doi.org/10.1002/cc.352

Bautsch, B. (2011). Reforming remedial education. National Conference of State Legislatures. Retrieved from http://www. ncsl. org/default. aspx.

Birenbaum, M., \& Tatsuoka, K. (1987). Open-ended versus multiple-choice response formats-It does make a difference for diagnostic purposes. Applied Psychological Measurement, 11, 385-395. 
http://dx.doi.org/10.1177/014662168701100404

Boylan, H. R., \& Saxon, D. (2002). What works in remediation: Lessons learning from 30 years of research. National Center for Developmental Education. Boone, NC: Appalachian State University.

Chan, M. (2013). Policy snapshot: Assessing and increasing college readiness in New England. New England Journal of Higher Education.

Crippen, K. J., \& Brooks, D. W. (2009). Applying cognitive theory to chemistry instruction: The case for worked examples. Chemistry Education Research and Practice, 10, 35-41. http://dx.doi.org/10.1039/b901458f

Crippen, K., Biesinger, K., Muis, K., \& Orgill, M. (2009). The Role of Goal Orientation and Self-Efficacy in Learning from Web-Based Worked Examples. Journal of Interactive Learning Research, 20(4), 385-403.

Eddy, R. M. (2000). Chemophobia in the college classroom: Extent, sources and student characteristics. Journal of Chemical Education, 77(4), 514-517. http://dx.doi.org/10.1021/ed077p514

Flores, R., \& Inan, F. (2014). Examining the impact of adaptively faded worked examples on student learning outcomes. Journal of Interactive Learning Research, 25(4), 467-485.

Galindo, B., Castaneda, S., Gutierrez, E., Tejada Jr., A., \& Wallace, D. (2014). Challenging our labels: Rejecting the language of remediation. Young Scholars in Writing, 11.

Hoffman, R., \& McGuire, S. Y. (2010). Learning and teaching strategies. American Scientist, 98, 6. http://dx.doi.org/10.1511/2010.86.378

Kalyuga, S., Chandler, P., Tuovinen, J., \& Sweller, J. (2001). When problem solving is superior to studying $\begin{array}{llll}\text { worked examples. Journal of Educational Psychology, 93(3), 579-588. } & \text {. }\end{array}$ http://dx.doi.org/10.1037/0022-0663.93.3.579

Kruger, J., \& Dunning, D. (1999). Unskilled and unaware of it: How difficulties in recognizing one's own incompetence lead to inflated self-assessment. Journal of Personality and Social Psychology, 77(6), 1121-1134. http://dx.doi.org/10.1037/0022-3514.77.6.1121

Kurbanoglu, N. I., \& Akim, A. (2010). The relationships between university students' chemistry laboratory anxiety, attitudes and self-efficacy beliefs. Australian Journal of Teacher Education, 35(8), 4. http://dx.doi.org/10.14221/ajte.2010v35n8.4

Martin, D., \& Arendale, D. (1994). Supplemental instruction: Increasing achievement and retention. San Fransico, CA: Jossey-Bass.

Moreno, R., Reisslein, M., \& Delgoda, G. M. (2006). Toward a fundamental understand of worked example instruction: Impact of means-ends practice, backward/forward fading, and adaptivity. American Society of Engineering Education Annual Conference. San Diego: American Society of Engineering Education.

National Conference of State Legislatures. (2012). Improving college completion-reforming remedial eduction. Retrieved from http://www.ncsl.org/issues-research/educ/improving-college-completion-reforming-remedia l.aspx

Paas, F., Renkly, A., \& Sweller, J. (2003). Cognitive load theory and instructional design: Recent developments. Educational psychologist, 38(1), 1-4. http://dx.doi.org/10.1207/s15326985ep3801_1

Palmer, E. J., \& Devitt, P. G. (2007). Assessment of higher order cognitive skills in undergraduate education: Modified essay or multiple choice questions? BMC Medical Education, 7(1), 49. http://dx.doi.org/10.1186/1472-6920-7-49

Rickey, D., \& Stacy, A. (2000). The role of metacognition in learning chemistry. Journal of Chemical Engineering, 77(7), 915-921. http://dx.doi.org/10.1021/ed077p915

Salden, R. J., Aleven, V. A., Renkl, A., \& Schwonke, R. (2009). Worked exampls and tutored problem solving: Redundant or synergistic forms of support? Topics in Cognitive Science, 1, 203-213. http://dx.doi.org/10.1111/j.1756-8765.2008.01011.x

Sweller, J., \& Cooper, G. (1985). The use of worked examples as a substitute for problem solving in learning algebra. Cognition and Instruction, 2, 59-89. http://dx.doi.org/10.1207/s1532690xci0201_3

Taconis, R., Ferguson-Hessler, M., \& Broekkamp, H. (2001). Teaching science problem solving: An overview of experimental work. Journal of Research in Science Teaching, 38(4), 442-468. http://dx.doi.org/10.1002/tea.1013 
Twenge, J. (2009). Generational changes and their impact in the classroom: Teaching generation me. Medical Education, 43, 378-405. http://dx.doi.org/10.1111/j.1365-2923.2009.03310.x

Venzia, A., Kirst, M., \& Antonio, A. (2004). Betraying the college dream: How disconnected K-12 and postsecondary systems undermine student aspirations. Standford University Bridge Project.

\section{Copyrights}

Copyright for this article is retained by the author(s), with first publication rights granted to the journal.

This is an open-access article distributed under the terms and conditions of the Creative Commons Attribution license (http://creativecommons.org/licenses/by/3.0/). 